\title{
Address Part Data Type
}

National Cancer Institute

\section{Source}

National Cancer Institute. Address Part Data Type. NCI Thesaurus. Code C95627.

A data type comprised of a portion of an address such as a street, house number, post box number, postal code, city or country. 